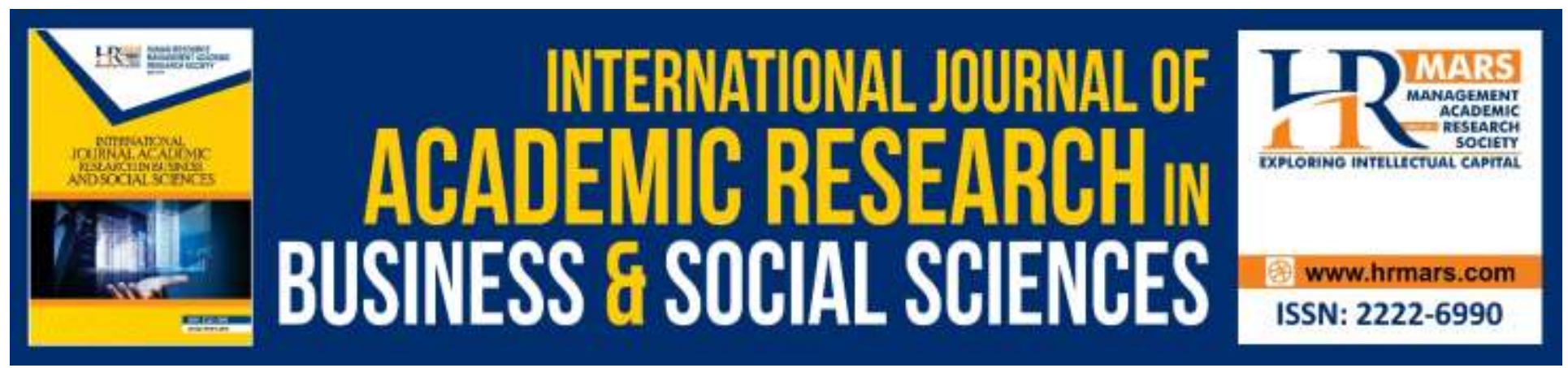

\title{
STEM Education: The Career Counselor's Roles and Responsibilities
}

Zaida Nor Zainudin, Sharifah Intan Sharina Syed Abdullah, Yusni Mohamad Yusop, Wan Norhayati Wan Othman

To Link this Article: http://dx.doi.org/10.6007/IJARBSS/v9-i11/6547

DOI:10.6007/IJARBSS/v9-i11/6547

Received: 10 October 2019, Revised: 30 October 2019, Accepted: 03 November 2019

Published Online: 13 November 2019

In-Text Citation: (Zainudin, Abdullah, Yusop, Othman, 2019)

To Cite this Article: Zainudin, Z. N., Abdullah, S. I. S. S., Yusop, Y. M., Othman, W.N. W. (2019). STEM Education: The Career Counselor's Roles and Responsibilities. International Journal of Academic Research in Business and Social Sciences, 9(11), 272-283.

\section{Copyright: (c) 2019 The Author(s)}

Published by Human Resource Management Academic Research Society (www.hrmars.com)

This article is published under the Creative Commons Attribution (CC BY 4.0) license. Anyone may reproduce, distribute, translate and create derivative works of this article (for both commercial and non-commercial purposes), subject to full attribution to the original publication and authors. The full terms of this license may be seen

at: http://creativecommons.org/licences/by/4.0/legalcode

Vol. 9, No. 11, 2019, Pg. 272 - 283

http://hrmars.com/index.php/pages/detail/IJARBSS

JOURNAL HOMEPAGE

Full Terms \& Conditions of access and use can be found at http://hrmars.com/index.php/pages/detail/publication-ethics 


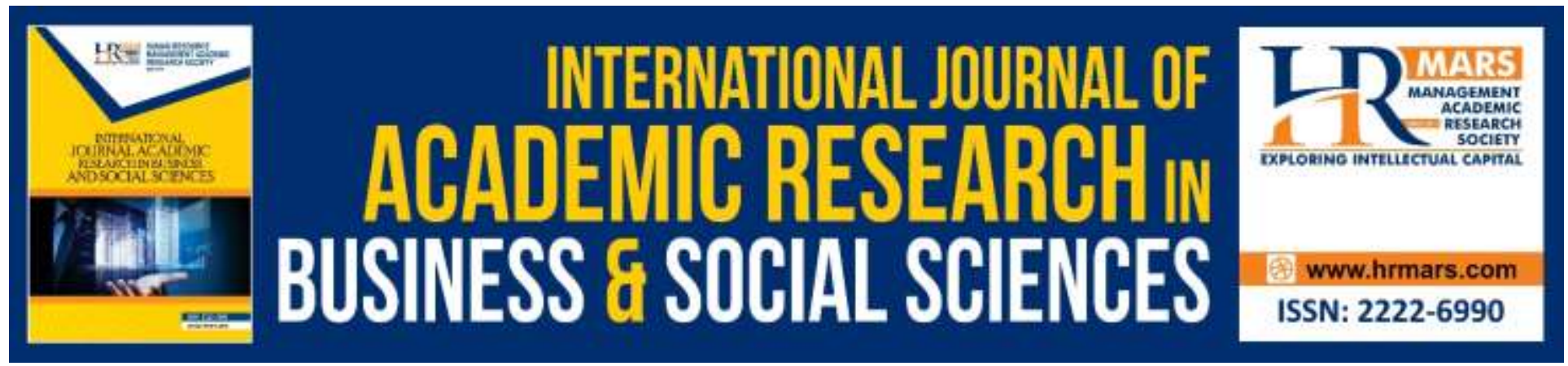

\title{
STEM Education: The Career Counselor's Roles and Responsibilities
}

\author{
Zaida Nor Zainudin, Sharifah Intan Sharina Syed Abdullah, Yusni \\ Mohamad Yusop, Wan Norhayati Wan Othman \\ University Putra of Malaysia, Selangor, Malaysia
}

\begin{abstract}
Some countries have adopted STEM policies in their education. Many policies, initiatives, training and funds are for STEM development aimed at expanding science, technology, engineering, and mathematical workforce. This education investment also aims to create a larger, more diverse group of talent pursuing technical careers. Counselors are among those who should actively involve in supporting and promoting STEM Education in school. This paper is to see the roles can be played by counsellors. This qualitative research involves 59 school counselors in Selangor, Malaysia. Research data was analyzed using nested analysis approach. The analysis is considered as nested in a way that it combines descriptive quantitative analysis with an in-depth thematic qualitative analysis. Thematic coding is applied in gathering the themes. Six themes emerged from the data. The themes are counsellor must be (a) well-versed in STEM, (b) giving information and understanding of STEM to students, (c) instill students' interest, (d) knowledgeable of stem career prospects, (e) knowledgeable in career psychometrics tests, and (f) be prepared with students' personal issues. We conclude that the role of a counsellor in school is extremely important to support and promote STEM Education.
\end{abstract}

Keywords: Counselor, School, Career Choice, Career Development

\section{Introduction}

Each individual is unique and has different personality. Personality also illustrates the individual's interest and tendency towards something especially if it involves his future such as the selection of a program of study which is certainly related to the determination of a person's career field. This is because every individual will find a career that suits his personality where he is able to demonstrate his abilities and skills and has the opportunity to show his excellence (Mohd, Salleha, \& Mustapha, 2010). The selection of a program of study or an appropriate career in line with personality is crucial in determining the individual's future. Imagine if an individual with deep interest and tendency to draw and paint was instructed to perform routine work on 
machine, would invite a conflict within him. Inconsistency in personality with the selection of program of study resulted in the student becoming less motivated and interested in continuing the learning session. Personalities are also being able to become legitimate predictors of individual work performance (Hough, \& Ones, 2001).

In today's world of the twenty-first century, the Education Policy of most countries began to focus on the STEM approach (Science, Technology, Engineering \& Mathematics). The term STEM began in the early 90's in the United States in US government policies (Koehler, Binns, \& Bloom, 2015). The definition of Integrated STEM as: "Teaching and learning of content and practice of science that incorporate the elements of Science and Mathematics by integrating Engineering and Engineering Design practices through the relevant Technology.

Engagements in STEM-related initiatives provide various opportunities for counselors, and have direct impact on their work. Counselor has additional role in career planning, so counselors must have the skills, knowledge, and necessary skills to facilitate in career counseling. With the knowledge gained through the STEM professional development, school counselors have the opportunity to gather teachers and administrators to create opportunities for career awareness for their school staff, students, and families. In addition, school counselors can continue to develop career courses and encourage potential students through career-related opportunities. On the reforms in this education system, the School Counselor should facilitate the planning of student courses in preparing for the STEM career world. School counselors should take part in student placement and have a direct opportunity to assign students to take courses that fit the career personality and academic achievement (Akos, Shoffner, \& Ellis, 2007). School counselors will be able to help students develop self-esteem and form realistic attitudes about the future career. The influence of school counselor's in career counseling is very important that the level of student's confidence in their abilities in mathematics and science predicts their interest in the STEM career path (Akos et al., 2007).

School counselors also need to integrate STEM knowledge into the interests of the students. Counselors should focus on positive attitudes and help students identify higher aspirations in seeing the opportunities of STEM education (Maher, \& Abu-Hilal, 2000). With these interests, counselors can help students develop their own learning experiences and skills that drive them towards their career choices. School counselors need to improve the orientation of the students' goals while working toward raising the potential of students who are likely to succeed in the areas of critical needs, such as mathematics and science (Trusty, \& Niles, 2004).

The delivery of information focused by STEM is indispensable for school counselors as they may not have experience in the subject and / or interest in STEM or career-related matters (Feller, 2009). However, many school counselors today may not be exposed to STEM focus during their studies, and the knowledge of counselors on current career development may be limited (Wyrick, 2004). Counselors enhance their own knowledge base so they can lead others (teachers, administrators and students) by sharing the latest information and promoting STEM focus at school. School counselors should use their rising knowledge to support student access to more intensive career counseling, more challenging mathematical and science courses, and more exposure to STEM-related programming. The counselor also needs to give an understanding of 
the active parent in setting the career goals of children by instilling the importance of career exploration (Jacobs, Chhin, \& Bleeker, 2006). Given the strong impact of parental support on the student's decision to continue STEM careers, counselors can use their skills and vision to share information and become parental advocates on the most effective way to determine their children's career in the STEM-based field.

Counselors can easily integrate various online resources for assimilation into career-related discussions. Resources provide activities to engage students in career search, teacher-use activities, movie clips related to STEM's career options and opportunities, STEM projects for student engagement, and many websites for students / parents (and school counselors). These resources help counselors increase the domain of new knowledge in empowering their knowledge. The counselor should take the opportunity to maximize STEM's career knowledge by leveraging some of the websites developed to get career information based on STEM (Feller, 2011), such as career opportunities, STEM-related program listings for undergraduate and postgraduate programs, games that allow students to explore their career and job opportunities, and other career development resources.

The STEM Careers Inventory provides a self-directed assessment using Holland's (1959) RIASEC (Realistic, Investigative, Artistic, Social, Enterprising, and Conventional) codes to help individuals identify and explore STEM fields (Shatkin, 2011). Counselors also need to be proficient in career counseling. The inherent inconsistency between the personality pattern and the selected course of study causes some students to learn under stress (Mahfar, Zaini, \& Nordin, 2007). Thus, the question arises whether the student is really interested in the selection of the previously created program in line with his or her personality or simply fulfilling the criteria of academic achievement to qualify. The alignment of personality with the environment of program selection will affect the success of a career (Bretz, \& Judge, 1994). And career choice must be in line with one's career interests because the choices they make are for their future. He added that this would be a problem if the choices were made unsuitable for his personality and he could cause tiredness and disappointment and cause the individual's performance to be disrupted (Lia, 2016).

Among the career theories can be the guide to the counselor is Holland's Career Theory. According to Holland (1985), personality patterns are aimed at describing individual personality profiles of Realistic (R), Investigative (I), Artistic (A), Social (S), Enterprising (E) and Conventional (C) personality characteristics. In short, ' $R$ ' personality tends to generate more technical, practical and hard-working skills that are abstract. 'I' Personality is more analytical, critical, and logical and tends to find a solution to a scientific problem. Individuals with ' $A$ ' personality are more creative and tend to be in the art, language, painting, music and writing aspects. The ' $S$ ' personality has a tendency in social activities and has good interpersonal and communication links. While 'E' personalities are more in leading, coaxing and directing and manipulating others for specific purposes and interests. Finally, ' $C$ ' personality has the tendency to do activities involving file management, data processing, report preparation and structured work capability. So for the excellent and potential students in STEM-related careers are students with Investigative 
personality (I) with CRI, RIA, ECR equivalents. However, career personalities can still be shaped and polished.

However, are the counselors at school aware of their new role in promoting and supporting STEM Education? The objective of this study is to list counselor's role in promoting and supporting STEM Education at schools.

\section{Methodology}

Qualitative research design was adapted for the study whose target population are school counselors in Selangor, one of the states in Malaysia. Research data was analyzed using nested analysis approach. The analysis is considered as nested in a way that it combines descriptive quantitative analysis with an in-depth thematic qualitative analysis.

The survey form was distributed through google doc that needs the respondents to respond in given time-frame. The survey consists of demographic data as well as open ended questions on what are counselor's role in promoting and supporting STEM education in schools.

\section{Findings \& Discussions}

Demography

TABLE 1

DEMOGRAPHY OF RESPONDENTS

\begin{tabular}{|c|c|c|}
\hline & $\begin{array}{r}N \\
59 \\
\end{array}$ & $\%$ \\
\hline \multicolumn{3}{|l|}{ Gender } \\
\hline Male & 12 & $20 \%$ \\
\hline Female & 47 & $80 \%$ \\
\hline \multicolumn{3}{|c|}{ Academic qualification } \\
\hline Bachelor Degree & 42 & $71 \%$ \\
\hline Master Degree & 12 & $20 \%$ \\
\hline Phd Degree & 5 & $9 \%$ \\
\hline
\end{tabular}

A total of 59 respondents participated in this study. The study uses a monkey survey method that is distributed to counselors at the school, using emails. A total of $12(20 \%)$ respondents are males and $47(80 \%)$ females. Their academic qualifications are 42 (71\%) with bachelor degree, $12(20 \%)$ with master degree and 5 (9\%) with PHD degree.

Themes

Six themes emerged from the data. The themes are counsellor must be (a) well-versed in STEM, (b) giving information and understanding of STEM to students, (c) instill students' interest, (d) knowledgeable of stem career prospects, (e) knowledgeable in career psychometrics tests, and (f) be prepared with students' personal issues. The frequency of each theme is as in Table 2. 
INTERNATIONAL JOURNAL OF ACADEMIC RESEARCH IN BUSINESS AND SOCIAL SCIENCES Vol. 9, No. 11, November, 2019, E-ISSN: 2222-6990 @ 2019 HRMARS

\begin{tabular}{|l|c|}
\hline \multicolumn{1}{|c|}{ THEME } & FREQUENCY \\
\hline Well-versed in STEM education & 8 \\
\hline $\begin{array}{l}\text { Giving information and understanding of } \\
\text { STEM education to students }\end{array}$ & 19 \\
\hline Instill students' interest & 21 \\
\hline Knowledgable of STEM career prospects & 19 \\
\hline Knowledgable in career psychometrics tests & 8 \\
\hline Be prepared with students' personal issues & 14 \\
\hline
\end{tabular}

Table 2: Themes and the frequency

Well-versed in STEM education

Counselors need to have clear knowledge and understanding of STEM education. Counselor's confidence level will increase as their knowledge evolves, so counselors need to find support structures and activities (Akos et al., 2007). Among the activities to develop understanding and knowledge are STEM professional development training, information with STEM-related careers, attending conference on STEM, and network with counselors and agencies. Information from this understanding will help students to understand, and see the potential and opportunities in this STEM education. In addition, as co-workers, counselors can also give enlightenment and understanding to academic teachers in ways and methods to integrate sole subjects and STEM. For example, they can help teachers to examine teacher's interactions with students on subjects of interest, support research activities in subjects related to STEM, work with teachers to identify issues and problems, and develop support systems for inquiries. This idea is mentioned by 8 respondents in this study, among are:

The counselor should increase knowledge in the four areas (R1)

Counselors need to be knowledgeable about the aspects emphasized in the STEM education system (R12)

The counselor must well-versed about STEM education in order to give correct information to students and later instill the interest in them (R20)

Counselors need to be proficient and knowledgeable in STEM education to enable STEM related information to be communicated effectively. (R22)

Counselors must master about the STEM education in order to provide early and advanced information to students on STEM (R23)

Counsellors should be well-understanding on STEM, the importance and the benefits in order to convey the information to students. (R25) 
a) Give information and understanding of STEM to students

The counselor also must give information and understanding of STEM education to the students. School counselors also need to integrate STEM knowledge into the interests of the students. Counselors should focus on positive attitudes and help students identify higher aspirations in seeing the opportunities of STEM education (Maher, \& Abu-Hilal, 2000). With these interests, counselors can help students develop their own learning experiences and skills that drive them towards their career choices.

The role of the counselor in STEM education is to give understanding and knowledge about the STEM education and focuses on the readiness of students to face challenges in the STEM career especially in research activities involving the mastery of 21st century skills (R5)

The role of counselors in STEM education is to attract and encourage students' interest towards science, technology, engineering and math subjects. Therefore, the role of counselor is very important giving exposure and advises about STEM education (R6).

I think that in STEM education, counselors act as individuals who are responsible for giving exposure and understanding to students about knowledge and career in STEM (R8)

Counselor should instill understanding in students who have interest on STEM thus able to help them to plan their career or courses accordingly (R14)

Counselor should encourage and expose students to STEM education so they can think critically and plan their future (R16).

The role of counselor is to encourage students to gain self-confidence, to cultivate interest and understanding (R17).

Counselor is the right person to promote and introduce about STEM education to the students. Counselors in school have the task to give out the information for the students to know what is STEM (R18).

The role of counselors in STEM education is to work closely with the teachers apply STEM curriculum to students as well as counselors themselves should educate the students about STEM education (R19).

b) Instill students' interest

Counselor also has the role to instill interest in students toward STEM education. To instill the interest, again the counselor must knowledgeable in the STEM education itself and also STEMrelated career prospects. Counselor can help students to understand their strength and potential and later instill interest towards STEM education. 19 respondents agree that counselor's role is to instill interest in students.

The STEM education for all students regardless of low or high academic achievement. STEM education can be tailored to their achievement. This means that all students deserve their creativity in STEM. The role of the counselor is to encourage the students. Their early exposure in STEM education will further enhance the students' interest (R3).

Counselor should address STEM education in order to instill students' interest especially in research, innovation and creation. (R5). 
The role of counselors in STEM education is to help students interested with STEM, apply and integrate STEM concepts or components to understand the problem and solve it creatively and innovatively (R9).

Encouraging students to master the STEM field, collaborating with teachers in teaching aspects to foster students' interest in science, technology and mathematics (R12).

The role of counselors is to motivate students to understand the STEM education better and instill interest in STEM (R13).

The role of counselor is to encourage students to have self-confidence, to cultivate interest and understanding in STEM education (R17).

The Counselor is responsible to ensure that every STEM-related program being held at schools will build up students' interest in STEM education (R20).

c) Knowledgeable of STEM career prospects

The School Counselor should facilitate in planning and preparing students for the STEM-career world. School counselors will be able to help students develop self-esteem and form realistic attitudes about the future. The knowledge of STEM-based careers is very important in helping students plan their career paths. 21 respondents mentioned the needs of counselors to be knowledgeable in STEM career prospects.

Alert to job opportunities that can be achieved through STEM Education and qualifications expected by employers (R1).

The role of counselors in STEM education is to introduce career prospects in the STEM field, identifying employment opportunities in STEM field and give early exposure to students. Counselors should provide students with information and awareness on job prospect in the field of STEM as well as the needs of the industry which include expected salary, academic path ada career advancement (R4).

Counselor must well-prepared with the career prospects, and also career plan, in order prepare students to become the highly skilled workers required by the industry (R7).

Counselor should be able to identify the career prospects in STEM and plan career program (R9).

Explore and discover new jobs that exist in the work-force in related to STEM education (R11).

Counselor should have information in new STEM-related jobs thus able to help students to plan their career or courses accordingly (R14).

Counselor in school have the task to give out the information for the students to know what is STEM and also know what are the career opportunities (R18).

Counselors play a role in providing information on STEM-related careers, in terms of career demand in the market in the future, career path, advantages \& limitations, and how those career benefits the nation (R22)

To disseminate the information and raise awareness on STEM education through programs like talk, exhibition, career guidance programs (R25). 
Among the role of counselor in stem education is to raise awareness about the advantages of stem education and correct perceptions of students in this field. Students are afraid to venture into this field as they can't relate to opportunities and career choices in the field of STEM. This should be corrected so that students will no longer see STEM education as a difficult because they are always criticized by negative impressions such as minimal job opportunities. This is because STEM is one of the areas that promises good salary returns. The counselor serves as an individual responsible for advising on career opportunities in the field of STEM (R29).

In my opinion, the role of counselors in STEM education is absolutely crucial. Looking at the multi-flow in STEM education, the role of counselors is essential in helping students to identify their potential. With the help of counselors they will better understand about their interests, potentials and tendencies in terms of careers and make it easier for them to choose the appropriate education stream for themselves. (R32).

Counselors play a role in identifying the potential of a student in science, technology, engineering and mathematics (STEM). Additionally, counselors need to identify the tendency of students to work in the STEM related field and to facilitate students to understand their future needs and interests in career (R41).

The role of counselors in STEM education is as an inspiration for students to pursue knowledge in exploration / inquiry learning. This is to enable students to think critically, solve problems and be essential to produce students who will become the highly skilled workers required by the industry (R53).

Counselor should focuses on the readiness of students to face challenges in the STEM career especially in research activities that involves the mastery of 21st century skills (R55).

Career counselors focuses on career in STEM field, draw the interest of students in this careers, runs a career exhibition leading to the STEN field, and educate students in the STEM career, and academic career paths (R58).

\section{d) Knowledgeable in career psychometrics tests}

School counselors should take part in student placement and have a direct opportunity to empower students to take courses that fit the career personality and student careers (Akos et al., 2007). Career choice must be in line with one's career interests because the choices they make are for their future (Lia, 2016). He added that this would be a problem if the choices were made unsuitable for his personality and he could cause tiredness and disappointment and cause the individual's performance to be disrupted. So, counselor must be knowledgeable in running and analyzing career psychometrics tests, such as Self-Directed Search (SDS), VocationalPreference Inventory (VPI), Strong-Campbell Interest Inventory (SCII) and others.

Counselors should use career personality tests in order to match the personality and careers interest of STEM education (R3).

Exploring student interest through career interest test (R12). 
Counselors can work with students with high STEM preference to set their course or career goals using instruments and tests (R14).

Counselor can relate STEM job choice using testing and measurement. Maybe these students can create psychology test with formula in the future (R15).

Helps to see the student's tendency by using the method of testing and assessment (instruments and inventories) of personality and career (R26).

The role of Counselors in STEM education is to help the development of student by conducting tests and inventory, such as test of personality and inventory of career interests. So, it can help students to plan their career path (R35).

f) Be prepared with students' personal issues

Students will encounter their personal issues in studying STEM such as career-personality mismatch, parents' demands, study skills, academic achievement, college enrolment etc. The counselor must aware with the disturbed students and offer helps. Aggressive yet consistent outreach program is essential to help these students.

Counselor must alert and sensitive to the issues arisen by STEM education, which demands high skills and high order thinking skills (R1).

To support student's emotionally and mentally so that they could achieve higher, to prevent unwanted mental disorders by means such as talks, programs, counselling, campaigns, psychological tests and etc (R2).

Counselors needs to attract students to counseling sessions, to share problems about their study or direction after graduation (R22)

Counselors act as a medium between parents and students when conflicts arise from parents wanting children to pursue in the field of STEM, but the child are keen towards social sciences (R23).

As a result of the STEM implementation, students who has no keen interest, they experience decline in their academic achievement. The child feels pressures to continue studying in this field. As result, academic performance is no longer a drive motivation to succeed in life (R23).

Counselor must always be ready to encourage, advice and listen to their problems / pressures faced and provide solutions or inspiration to them (R27).

The role of counselors on STEM education is to provide an effective explanation for changing the notion of students to be more positive. In addition, counselors also need to think of appropriate therapy for students who have phobia on the STEM subjects (R50).

\section{Conclusion}

Meeting the national demand to grow the STEM workforce is tied to growing the STEM participation of individuals from groups who have been historically underrepresented in these fields. As key players in developing the future workforce, Counselors need culturally relevant interventions informed by career theory and research to increase equitable opportunities in STEM for all individuals across the life span (Schmidt, Hardinge, \& Rokutani, 2012). The 
counselors must well-versed in STEM Education in order to give information and understanding to the students. Counselors also must also be knowledgeable in STEM-related career prospects and career development so the counselor can instill students' interest in STEM education. Counselor must also knowledgeable in administering psychometrics tests especially for career choice and career development so the students can have aligned personality and career choice. And counselors also must always be alert and prepared to deal with issues related to STEM educations such as in study skills, academic achievement and also parents demand. School administrators, teachers and counselors must work together closely to make this holistic education policy successfully benefited the students.

\section{Acknowledgement}

This paper is part of the project by the initiative of Putra Grant 2018.

\section{Corresponding Author}

Dr Zaida Nor Zainudin,

Universiti Putra Malaysia,

Selangor, Malaysia.

Email: zaidanor@upm.edu.my

\section{References}

Akos, P., Shoffner, M., \& Ellis, M. (2007). Mathematics placement and the transition to middle school. Professional School Counseling, 10(3), 238-244.

Bretz, R. D., \& Judge, T. A. (1994). Person-organization fit and the theory of work adjustment: Implications for satisfaction, tenure, and career success. Journal of Vocational Behavior, 44(1), 32-54.

Bryan, L. A., Moore, T. J., Johnson, C. C., \& Roehrig, G. H. (2016). Stem Road Map: A Framework For Integrated Stem Education. NY: Routledge.

Feller, R. (2009). Stem centric career development: Sputnik ii or a thud? Career Planning \& Adult Development Journal, 25(1), 19-35.

Feller, R. (2011). Advancing the stem workforce through stem-centric career development. Technology and Engineering Teacher, 71(1), 6-12.

Hough, L. M., \& Ones, D. S. (2001). Handbook of Industrial, Work, and Organizational Psychology. London: Sage.

Jacobs, J. E., Chhin, C. S., \& Bleeker, M. M. (2006). Enduring links: Parents' expectations and their young adult children's gender-typed occupational choices. Educational Research and Evaluation, 12, 395-407.

Koehler, C., Binns, I. C., \& Bloom, M. A. (2015). The emergence of STEM. In STEM Road Map: A Framework for Integrated STEM Education, 13-22

Lia, D. F. (2016). The school counselor and STEM career development. Journal of Career Development, 44(4), 1-16. 
Maher, M., Abu-Hilal, M. M. (2000). A structural model of attitudes towards school subjects, academic aspiration and achievement. Journal Educational Psychology, 20(1), 75-84.

Mahfar, M., Zaini, F., \& Nordin, N. A. (2007). Analisis faktor penyebab stres di kalangan pelajar UTM. Kemanusiaan, 62 - 71.

Mark J. G., Jennifer F., Angela B. W., Anne-Barrie, H., \& Jo, H. (2013). Increasing persistence of college students in STEM. Science, 341(6153), 1455-1456.

Mohd, F., Salleha, A. M. \& Mustapha, R. (2010). The influence of contextual aspects on career decision making of Malaysian technical students. Social and Behavioral Sciences, 7(2), 369375.

Schmidt, C. D., Hardinge, G. B., Rokutani, L. J. (2012). Expanding the school counselor repertoire through stem-focused career development. Career Development Quarterly, 60(1), 25-35.

Shatkin, L. (2011). Quick STEM careers guide. Indianapolis, IN: JIST Publishing.

Shatkin, L. (2011). STEM Careers Inventory. Indianapolis, IN: JIST Publishing.

Trusty, J., \& Niles, S. G. (2004). Realized potential or lost talent: High school variables and bachelor's degree completion. Career Development Quarterly, 53, 2-15.

Wyrick, L. (2004). A Qualitative Study of Secondary School Counselor's Perceived Competencies in Student Career Development (Unpublished dissertation). Greely, CO: University of Northern Colorado. 